\title{
Clusterin is expressed in the anterior and intermediate lobes, but not in the posterior pituitary of sheep
}

\section{J S Fleming, N M Hope and C J Bolter}

Department of Physiology and Centre for Gene Research, University of Otago School of Medical
Sciences, PO Box 913, Dunedin, New Zealand

(Requests for offprints should be addressed to J S Fleming, Department of Anatomy and Structural Biology, University of Otago School of Medical Sciences, PO Box 913, Dunedin 9001, New Zealand)

\begin{abstract}
We have examined the expression of the ovine clusterin gene in the sheep pituitary gland, with the aim of determining its site of synthesis in this tissue. Northern blotting analysis of extracted polyadenylated RNA, using a ${ }^{32} \mathrm{P}$-labelled rat clusterin cDNA probe, detected the greatest amounts of clusterin mRNA in the anterior part of dissected pituitary glands. In situ hybridisation studies showed clusterin mRNA in anterior and intermediate pituitary cells, with lower amounts in vascular endothelium and posterior pituicytes. Clusterin protein, detected by immunohistochemistry, was observed in some
\end{abstract}

single secretory cells, within the capillary lumen and in cells around capillaries in the anterior and intermediate lobes, but no immunoreactivity was observed in posterior pituitary tissue. The pattern of clusterin expression in anterior and intermediate pituitary cells suggests possible roles for the protein in secretory cell turnover and/or hormone secretion or lipid uptake. Clusterin does not appear to be involved in ovine posterior pituitary hormone neurosecretion.

Fournal of Molecular Endocrinology (1999) 23, 199-208

\section{INTRODUCTION}

Clusterin is a highly sulphated glycoprotein that is expressed in a wide range of tissues, often in association with tissue remodelling or apoptosis, in response to injury or pathology, or connected with lipid transport or atherosclerotic vascular disease (Fritz \& Murphy 1993). It is expressed in many endocrine tissues, including ovary, testis, prostate and uterus (Sylvester \& Griswold 1995), pancreas (Scaglia et al. 1995) and breast tissue (Tenniswood et al. 1992, Welsh 1994). Clusterin is known to be an adrenal chromaffin granule constituent and its expression increases in the adrenal in response to histamine or forskolin treatment (Palmer \& Christie 1990, Laslop et al. 1993). In gonadal tissue, large amounts of clusterin mRNA have been measured in extracts of ovine corpora lutea (Fleming et al. 1992) and high concentrations of clusterin protein are synthesised in the ram rete testis (Tung \& Fritz 1985).

There is further evidence for a role for this protein in search of a function (Fritz 1995) in neural tissue, where its expression is upregulated in pathologies such as Alzheimer's disease (Finch \& May 1995). Clusterin is induced in reactive astrocytes in response to neurotoxic injury ( $Z_{\text {wain }}$ et al. 1994, Walton et al. 1996, Tornquist et al. 1997) and appears to have a protective role in the brain, possibly acting as a local inhibitor of the complement cascade (Tornquist et al. 1996).

Clusterin expression is known to be suppressed by gonadal steroids in prostate, mammary gland and uterus (Bettuzzi et al. 1992, Wunsche et al. 1998) and by glucocorticoids in brain and kidney cells (Finch \& May 1995, Gutacker et al. 1996). These observations led us to investigate clusterin expression in the ovine pituitary gland, with the aim of determining the distribution of clusterin mRNA and protein in the different parts of this tissue. In previous studies of bovine pituitary, the protein was detected in both the anterior and posterior lobes (Laslop et al. 1993). However, the site of clusterin mRNA transcription remains unclear. Aronow et al. (1993) did not detect clusterin mRNA in mouse anterior pituitary, whereas Laslop et al. (1993) detected it by Northern blotting in both anterior and posterior 
lobes. We have used RNA expression analysis, immunohistochemistry and in situ hybridisation to investigate clusterin synthesis in the ovine pituitary gland.

\section{MATERIALS AND METHODS}

\section{Animals}

All experiments were performed in accordance with the 1987 Animal Protection (Codes of Ethical Conduct) Regulations of New Zealand after approval was granted by the University of Otago Committee on Ethics in the Care and Use of Laboratory Animals.

For Northern blotting experiments the heads of adult ewes were obtained from the local abattoir and the brain and pituitary gland removed as rapidly as possible. Pituitary glands were dissected into the stalk median eminence, a dorsal strip containing neuronal axons, a posterior portion and the remaining anterior portion. Samples of medial basal hypothalamus, cerebral cortex, optic chiasma, spinal cord and cerebellum were collected for comparison. All tissues were frozen on dry ice and stored at $-80{ }^{\circ} \mathrm{C}$ until extraction. Ram lamb pituitary mRNA (Fleming et al. 1997) was used as a positive control on Northern blots probed with the growth hormone gene probe.

Pituitary glands for immunohistochemistry and in situ hybridisation were obtained from five 4- to 6-year-old Romney ewes killed with Euthatal (Southern Veterinary Supplies, Christchurch, New Zealand; $100 \mathrm{mg} / \mathrm{kg}$, i.v.), at the mid-luteal phase of the oestrous cycle. Whole glands were removed from the skull within 10 min of death, embedded in OCT compound (Tissue Tek, Bayer Diagnostics Ltd, Christchurch, New Zealand), frozen on dry ice and stored at $-80^{\circ} \mathrm{C}$ until required.

\section{Poly(A)-enriched RNA extraction}

Poly(A)-enriched RNA was extracted from 0.3$0.5 \mathrm{~g}$ samples, as previously described (Fleming et al. 1992). Poly(A)-depleted RNA remaining in solution after affinity chromatography on oligo(dT) cellulose was ethanol precipitated and resuspended in RNase-free water. The yield of RNA was estimated spectrophotometrically from absorbance at $260 \mathrm{~nm}\left(\mathrm{~A}_{260}\right)$ and the purity of the poly(A)enriched RNA from the $A_{260} / A_{280}$ ratio.

\section{Gene probes}

Rat clusterin (Cheng et al. 1988) and ovine growth hormone (Fleming et al. 1997) cDNA probes were verified by restriction analysis. Isolated insert was labelled with $\left[\alpha-{ }^{32} \mathrm{P}\right] \mathrm{dCTP}$ to specific activities $>1 \times 10^{8}$ c.p.m./ $\mu$ g using random primers (Feinberg \& Vogelstein 1983). Labelled probes were denatured at $95-100{ }^{\circ} \mathrm{C}$ for $5 \mathrm{~min}$ before hybridisation.

For in situ hybridisation studies, the rat clusterin cDNA was digested with BstXI (New England Biolabs Inc., Beverley, MA, USA) and ${ }^{33}$ P-labelled cRNA riboprobes were transcribed with T7 (antisense) and SP6 (sense) RNA polymerases using the Riboprobe Gemini System II (Promega, Dade Behring Diagnostics Ltd, Auckland, New Zealand).

\section{Northern blotting and hybridisation}

Poly(A)-enriched and -depleted RNA samples $(2 \mu \mathrm{g})$ were denatured, electrophoresed and blotted onto Hybond-N nylon filters (Amersham International, Amersham, Bucks, UK) as previously described (Fleming et al. 1992). The RNA was stained routinely with $1 \mu \mathrm{g}$ ethidium bromide per $2 \mu \mathrm{g}$ sample, added before denaturation (Gong 1992). In order to assess the amounts of RNA added to each lane, the ethidium bromide-stained gel photographs were scanned using reflectance densitometry (Bio-Rad Video Densitometer Model 620; Bio-Rad, Richmond, CA, USA) (Fleming et al. 1992).

Blots were hybridised with an $\left[\alpha-{ }^{32} \mathrm{P}\right] \mathrm{dCTP}-$ labelled cDNA probe for $20 \mathrm{~h}$ at $65^{\circ} \mathrm{C}$ and washed to a final stringency of $0 \cdot 1 \times \operatorname{SSC}(1 \times \mathrm{SSC}$ is $15 \mathrm{mM}$ sodium citrate plus $150 \mathrm{mM}$ sodium chloride) and $0 \cdot 1 \%(\mathrm{w} / \mathrm{v}) \mathrm{SDS}$ at $65^{\circ} \mathrm{C}$. Autoradiographs were scanned on the densitometer and the density of the signal from each sample was normalised by dividing it by the density of the ethidium bromide staining at $2 \mathrm{~kb}$ for that sample.

\section{In situ hybridisation}

The method of in situ hybridisation described by Leeuwenberg et al. (1995) was modified for use with ovine pituitary glands. Frozen OCT-embedded pituitary glands were sectioned to a thickness of $10 \mu \mathrm{m}$ and thaw-mounted onto Superfrost Plus slides (BDH Ltd, Poole, Dorset, UK). Frozen sections were fixed in $4 \%(\mathrm{v} / \mathrm{v})$ diethyl pyrocarbonate (DEPC; $\mathrm{BDH})$-treated paraformaldehyde/PBS $\left(0.14 \mathrm{M} \mathrm{NaCl}, 2.7 \mathrm{mM} \mathrm{KCl}, 10 \mathrm{mM} \mathrm{Na} \mathrm{HPO}_{4}\right.$, $\left.1.8 \mathrm{mM} \mathrm{KH} \mathrm{PO}_{4}\right), \mathrm{pH} 7 \cdot 4$ for $20 \mathrm{~min}$ and washed in DEPC-treated PBS (the second wash included $0 \cdot 1 \mathrm{M}$ glycine). The tissue was treated for $10 \mathrm{~min}$ with $1 \mu \mathrm{g} / \mathrm{ml}$ proteinase $\mathrm{K}$ (Boehringer Mannheim $\mathrm{GmbH}$, Mannheim, Germany) in $0 \cdot 1 \mathrm{M}$ Tris-HCl $(\mathrm{pH} 8 \cdot 0), \quad 50 \mathrm{mM}$ EDTA at $37^{\circ} \mathrm{C}$, washed in 
DEPC-treated PBS and acetylated in $0 \cdot 25 \%(\mathrm{v} / \mathrm{v})$ acetic anhydride in $0.1 \mathrm{M}$ triethanolamine $(\mathrm{pH} 8)$ at room temperature, before dehydration. Prior to hybridisation, negative controls were treated for $30 \mathrm{~min}$ at $37^{\circ} \mathrm{C}$ with $20 \mu \mathrm{g} / \mathrm{ml}$ RNase A (Boehringer Mannheim) in $0.5 \mathrm{M} \mathrm{NaCl}, 10 \mathrm{mM}$ Tris-HCl (pH 8.0) and $1 \mathrm{mM}$ EDTA.

Sections were hybridised under coverslips overnight at $42{ }^{\circ} \mathrm{C}$ with $30 \mu \mathrm{l}$ hybridisation buffer containing approximately 30000 c.p.m. ${ }^{33} \mathrm{P}$-labelled clusterin antisense or sense riboprobe, $50 \%(\mathrm{v} / \mathrm{v})$ deionised formamide, $0.3 \mathrm{M} \mathrm{NaCl}, 10 \mathrm{mM}$ Tris$\mathrm{HCl}(\mathrm{pH} 6 \cdot 8), 10 \mathrm{mM} \mathrm{NaPO}_{4}, 5 \mathrm{mM}$ EDTA, $1 \times$ Denhardt's solution $(0.02 \% \quad(\mathrm{w} / \mathrm{v}) \quad$ Ficoll 400 (Sigma-Aldrich, St Louis, MO, USA), 0.025\% $(\mathrm{w} / \mathrm{v})$ polyvinylpyrrolidone (Sigma), $0 \cdot 02 \% \mathrm{BSA}$ ), $10 \% \quad(\mathrm{w} / \mathrm{v})$ dextran sulphate (Sigma), $50 \mathrm{mM}$ dithiothreitol (Boehringer Mannheim), $1 \mathrm{mg} / \mathrm{ml} E$. coli tRNA (Boehringer Mannheim). The slides were washed twice for $30 \mathrm{~min}$ in $50 \%$ formamide in $2 \times \mathrm{SSC}$, twice for $30 \mathrm{~min}$ in $2 \times \mathrm{SSC}$ and twice for $30 \mathrm{~min}$ in $1 \times \mathrm{SSC}$ at $50^{\circ} \mathrm{C}$. Sections were then incubated in $20 \mu \mathrm{g} / \mathrm{ml}$ RNase A (Boehringer Mannheim) in $0.5 \mathrm{M} \mathrm{NaCl}, 10 \mathrm{mM}$ Tris-HCl (pH $8 \cdot 0), 1 \mathrm{mM}$ EDTA for $30 \mathrm{~min}$ at $37^{\circ} \mathrm{C}$, washed and dehydrated through increasing concentrations of ethanol containing $0.3 \mathrm{M}$ ammonium acetate.

The slides were then exposed overnight to Kodak BioMax film (Eastman Kodak, Rochester, NY, USA) to detect hybridisation signals, before being dipped in Hypercoat emulsion (Amersham) and exposed for $5-7$ days at $4{ }^{\circ} \mathrm{C}$ in light-tight boxes containing silica gel. The sections were lightly counterstained with haematoxylin, dehydrated, cleared, and examined by both dark- and brightfield light microscopy.

\section{Immunohistochemistry}

Frozen OCT-embedded pituitary glands were sectioned to a thickness of $10 \mu \mathrm{m}$ and thaw-mounted onto gelatin-coated slides. Sections were fixed in $4 \%$ $(\mathrm{w} / \mathrm{v})$ paraformaldehyde in $0 \cdot 1 \mathrm{M}$ phosphate buffer ( $\mathrm{pH} 7 \cdot 4$ ) for $20 \mathrm{~min}$ and washed in PBS, $\mathrm{pH} 7 \cdot 4$. The sections were permeabilised in $0.1 \%(\mathrm{w} / \mathrm{v})$ Triton X-100 in PBS and treated with $0 \cdot 6 \%(\mathrm{v} / \mathrm{v})$ hydrogen peroxide in methanol for $10 \mathrm{~min}$. After two 5 min PBS washes, the sections were incubated in $1 \%(\mathrm{v} / \mathrm{v})$ normal sheep serum in PBS for $30 \mathrm{~min}$ to reduce non-specific binding. The slides were incubated with a specific monoclonal antibody immunoglobulin $\left(\operatorname{IgG}_{1}\right)$ against sheep clusterin (HCn 17, a gift from the late Prof. Irving Fritz, Babraham, Cambridge, UK; Blaschuk \& Fritz 1984, Tung \& Fritz 1985) diluted 1:10000 in PBS containing $0 \cdot 5 \%(\mathrm{w} / \mathrm{v})$ BSA (Sigma, RIA grade) for
$30 \mathrm{~min}$, before incubation with biotinylated sheep anti-mouse antibody (Amersham) diluted 1:500 in PBS containing 0.5\% BSA. Sections were incubated in biotin-streptavidin-horse radish peroxidase (HRP) complex (Amersham) diluted 1:200 in PBS containing $0 \cdot 5 \% \mathrm{BSA}$ for $25 \mathrm{~min}$ and the HRP was detected using the chromogen, diaminobenzidene. Slides were examined under bright-field and phase contrast optics using a Zeiss Axioplan light microscope (Carl Zeiss NZ Ltd, Lower Hutt, New Zealand). Adjacent sections were counterstained with haematoxylin and eosin after anti-clusterin immunohistochemistry. Controls included serial dilution of anti-clusterin, omission of anti-clusterin and application of mouse IgG instead of anticlusterin. The anti-clusterin monoclonal antibody (Blaschuk \& Fritz 1984, Tung \& Fritz 1985, Rosenior et al. 1987) was effective in dilutions up to 1:20000 and was used at 1:10 000. There was no staining in the absence of anti-clusterin or with the application of mouse $\mathrm{IgG}$ at a concentration of five times that used for anti-clusterin.

\section{RESULTS}

Northern blot analysis of poly(A)-enriched RNA from all brain and pituitary samples revealed three clusterin mRNA transcripts of $2 \cdot 3,3.0$ and $4 \cdot 4 \mathrm{~kb}$. The $2 \cdot 3 \mathrm{~kb}$ band was absent from poly(A)-depleted extracts and the larger bands were stronger in poly(A)-enriched RNA than in poly(A)-depleted samples (Fig. 1a). The rat clusterin cDNA probe bound strongly to the ribosomal RNA bands at $5 \cdot 0$ and $2 \cdot 1 \mathrm{~kb}$ in Northern blots of total cellular RNA extracts (data not shown).

The ovine growth hormone cDNA probe detected a single mRNA transcript at $1.0 \mathrm{~kb}$ (Fig. $1 b)$, as previously reported (Fleming et al. 1997). Growth hormone hybridisation was detected only in pituitary extracts (Fig. 1b). There was considerable growth hormone hybridisation with poly(A)enriched RNA extracted from the dorsal edge and posterior pituitary, confirming that these dissected regions contained significant amounts of anterior and intermediate lobe. Pituitary mRNA extracts from ram lambs gave a stronger hybridisation signal than those from adult ewes. No attempt was made to quantitate growth hormone hybridisation.

The density of the clusterin signal was highest in mRNA extracts from the anterior pituitary, spinal cord and hypothalamus and lowest in the dorsal strip and posterior pituitary extracts and white matter from the optic chiasma. Clusterin hybridisation densities obtained from three to five different 
a

POLY(A)-DEPLETED RNA

POLY(A)-ENRICHED RNA

MBH ME DP PP AP SC OC CB MBH ME DP PP AP SC OC CB

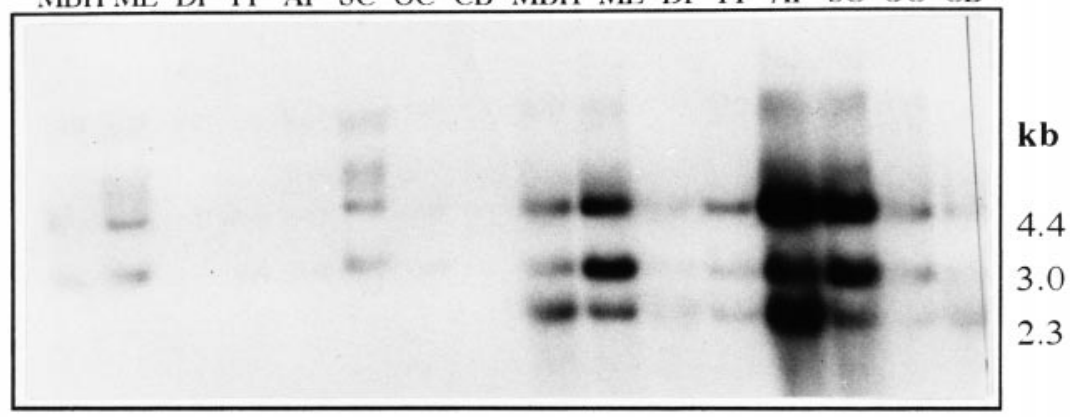

b

POLY(A)-ENRICHED RNA

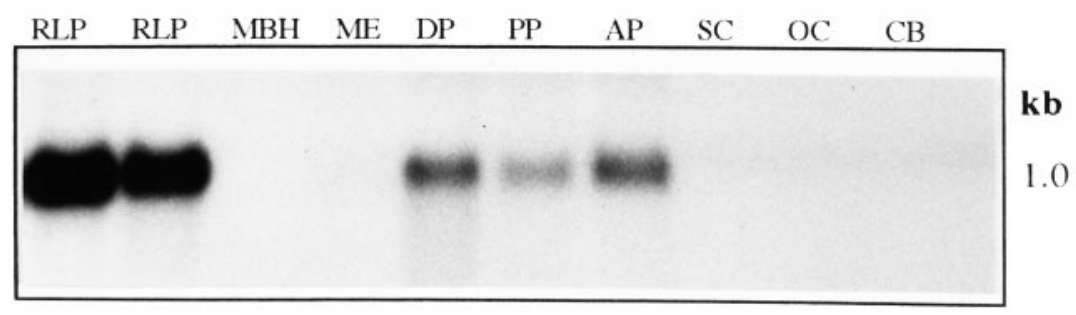

FIGURE 1. Northern analysis of mRNA from extracts of dissected ovine pituitary glands and brain samples. (a) Clusterin hybridisation signals in samples of poly(A)-enriched and -depleted RNA from the dorsal edge of the pituitary (DP), the posterior pituitary (PP), the anterior pituitary (AP), median eminence (ME), medial basal hypothalamus $(\mathrm{MBH})$, optic chiasma (OC), spinal cord (SC) and cerebellum (CB) of adult ewes. (b) Growth hormone mRNA hybridisation in extracts of brain and dissected pituitary glands from adult ewes and from two ram lamb pituitaries (RLP).

ewes and normalised with respect to the ethidium bromide staining (arbitrary units) are shown in Fig. 2 (mean \pm s.D.).

\section{In situ hybridisation}

In situ hybridisation with the clusterin antisense riboprobe revealed a high density of silver grains throughout the anterior and intermediate pituitary lobes (Fig. 3B and E). Silver grains did not appear to be associated with any particular cell type or structures such as capillaries. A lower grain density was apparent in the posterior pituitary, where the cell density was also lower (Fig. 3B and E). A low grain density was also observed when the tissue was probed with the control sense riboprobe (Fig. 3C and $\mathrm{F}$ ).

\section{Immunohistochemistry}

Immunohistochemistry with ovine anti-clusterin showed strong immunoreactivity present in the capillary endothelium and lumen of the anterior and intermediate lobes of the pituitary. Clusterin protein was evident within the capillaries in many sections (Fig. 3D and Fig. 4A and B). Isolated single cells within the anterior and intermediate lobes were also stained with the anti-clusterin antibody (Fig. 3D and Fig. 4A and B). In contrast, the pituicytes and capillary endothelium of the posterior lobe of the ovine pituitary were unreactive (Fig. 3A and Fig. 4A). Clusterin-immunopositive cells did not appear to be a specific anterior pituitary cell type. A small number of both acidophilic and basophilic cells (common in the intermediate lobe) 


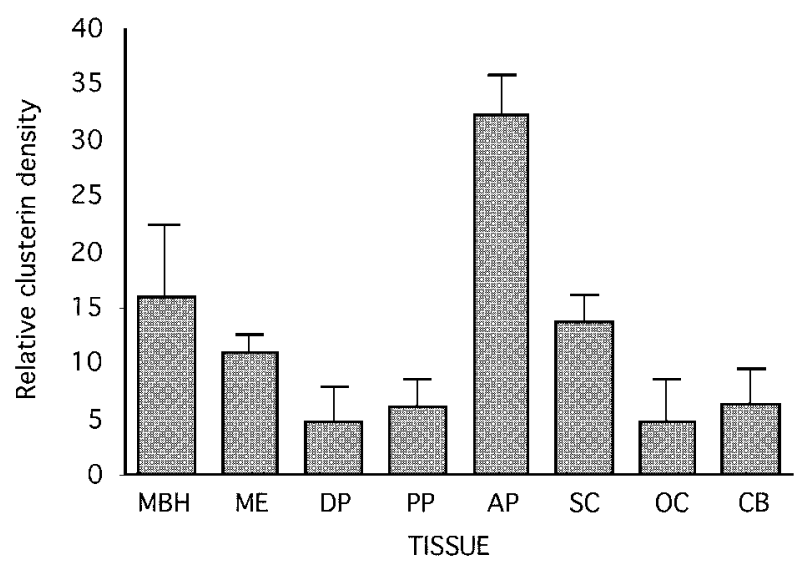

FIGURE 2. Mean \pm S.D. of clusterin hybridisation density at $2.3 \mathrm{~kb}$, normalised against ethidium bromide staining density (arbitrary units), in adult ewe brain and pituitary extracts. Mean relative densities were calculated from results from three (median eminence (ME) and spinal cord (SC)), four (posterior pituitary $(\mathrm{PP})$ and cerebellum $(\mathrm{CB})$ ) or five (medial basal hypothalamus $(\mathrm{MBH})$, dorsal edge of the pituitary (DP), anterior pituitary (AP) and optic chiasma (OC)) poly(A)-enriched RNA samples, extracted from different animals.

were immunopositive for clusterin (results not shown). There did not appear to be specific groups or clusters of immunopositive cells, or areas of the anterior and intermediate sheep pituitary gland in which cells stained preferentially (Fig. 3A). Cells that contained clusterin protein did not show an accumulation of silver grains after in situ hybridisation of adjacent sections, suggesting that the stained cells were not expressing high amounts of clusterin mRNA (Fig. 3A-C).

\section{DISCUSSION}

Northern analysis of pituitary extracts showed that clusterin expression occurred predominantly in the ovine anterior pituitary gland, with low concentrations of clusterin mRNA found in the posterior lobe extracts. This finding is similar to that of Laslop et al. (1993), who observed higher amounts of mRNA in bovine anterior pituitary extracts, but clusterin protein in both pituitary lobes. In the sheep brain extracts analysed, the highest clusterin hybridisation densities were found in the medial basal hypothalamus and spinal cord, both areas in which neuronal clusterin gene expression has been reported (Messmer-Joudrier et al. 1996, Wener et al. 1997). In previous studies on clusterin expression in sheep (Fleming et al. 1992), much higher amounts of clusterin mRNA were observed by Northern analysis in the liver and gonads than in the pituitary.

Three bands of clusterin hybridisation at $2 \cdot 3,3 \cdot 0$ and $4.4 \mathrm{~kb}$ were observed on Northern blots of ovine brain and pituitary poly (A)-enriched RNA, using a double-stranded, ${ }^{32} \mathrm{P}$-labelled cDNA probe. Previous studies with single-stranded, antisense riboprobes detected a single hybridisation band at $2 \cdot 2 \mathrm{~kb}$ in a variety of sheep tissue extracts (Fleming et al. 1992). Wunsche et al. (1998) also reported a second band of clusterin hybridisation at $3.9 \mathrm{~kb}$, in Northern blots of rat endometrium or endometrial adenocarcinoma cell lines. Levels of both mRNA transcripts were upregulated by oestradiol-17 $\beta$ treatment. In the study reported here, $\operatorname{poly}(\mathrm{A})$ depleted RNA showed a substantially reduced signal for all three bands and especially for the $2.3 \mathrm{~kb}$ band, which suggests that the higher bands were not generated by non-specific binding to ribosomal RNA. Because the identity of the larger species was not verified, only the density of the $2 \cdot 3 \mathrm{~kb}$ band was used in the semi-quantitative comparison of clusterin expression in different tissues.

The in situ hybridisation studies confirmed the findings of the Northern blotting analysis, but did not clearly define which anterior and intermediate pituitary cells expressed clusterin mRNA. Although it could be argued that the density of cell bodies in the posterior pituitary was lower than in the anterior or intermediate lobes, the density of silver grains over the posterior pituitary sections was similar to that seen with the control sense riboprobe in all pituitary lobes and there were no noticeable clusters of silver grains over specific posterior pituitary cells. In the anterior and intermediate lobes it appeared that many cells were synthesising clusterin mRNA. There was no strong evidence that the cells which stained with anti-clusterin immunoreactivity were synthesising more mRNA (Fig. 3A-C). The endothelial lining and the lumen of many of the anterior and intermediate pituitary capillaries were often heavily stained for clusterin protein, but there was no evidence for specific silver grain accumulation to indicate that the clusterin gene was being expressed at a higher rate in the endothelial cells. Clusterin immunostaining was observed in both acidophilic pituitary cells, thought to include somatotrophs and mammotrophs, and basophilic pituitary cells, which may be gonadotrophs or thyrotrophs (Burkitt et al. 1993). No specific cell type appeared to be preferentially stained, nor was there a higher density of clusterin-positive cells in any part of the anterior or intermediate lobes. 

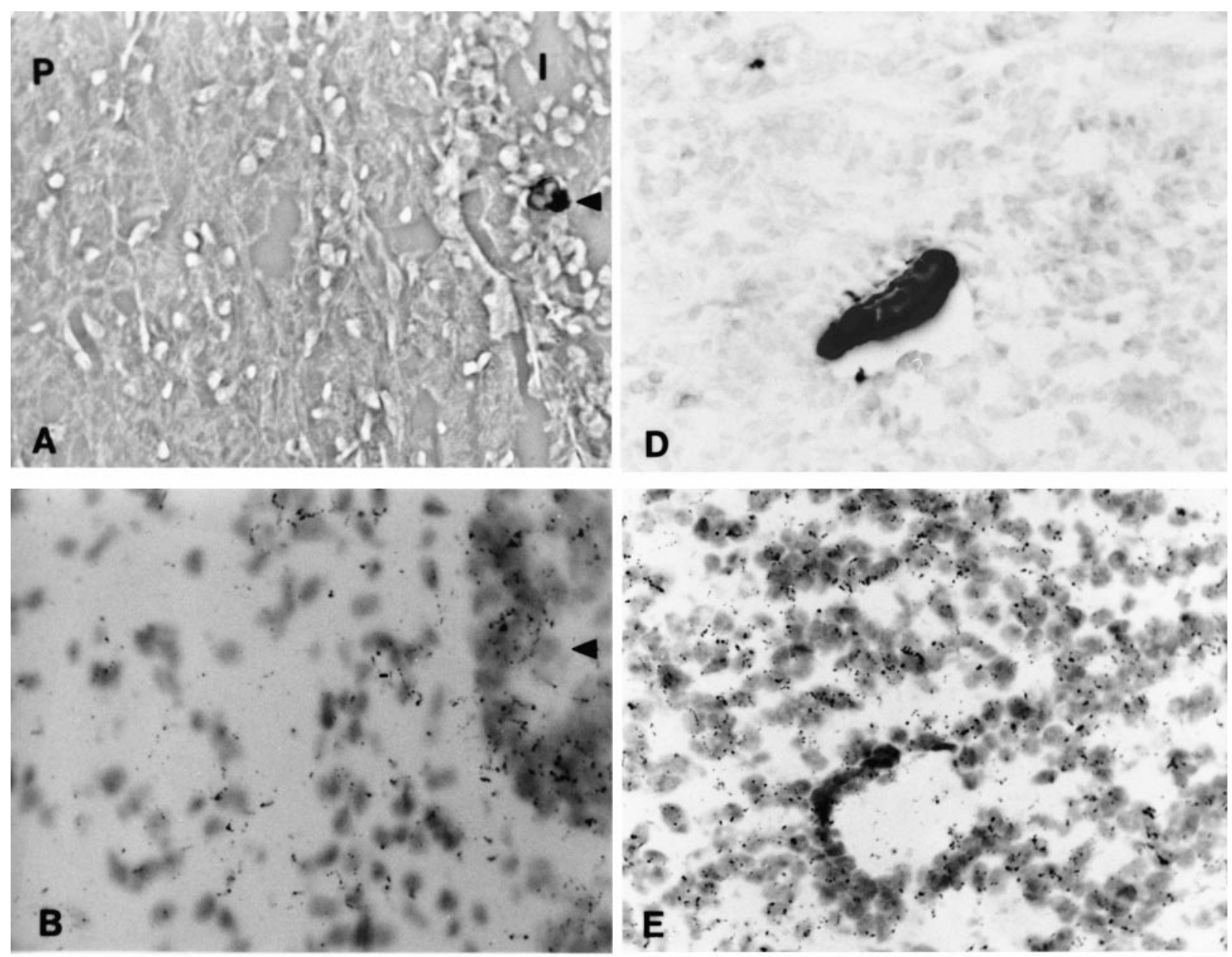

(3) 4.0.

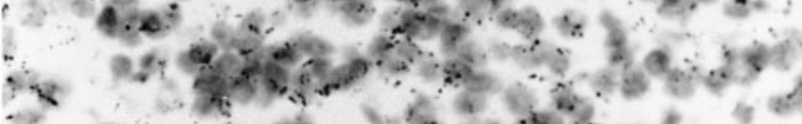
F.

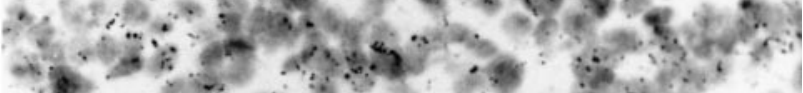

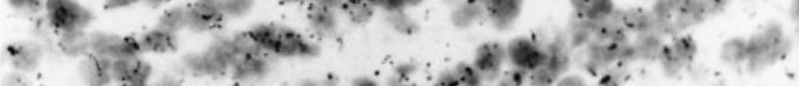

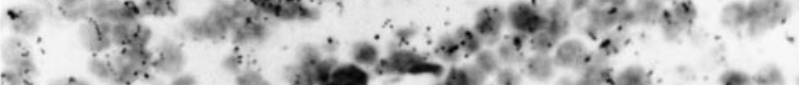

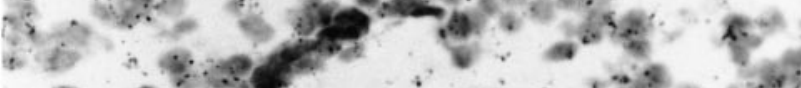

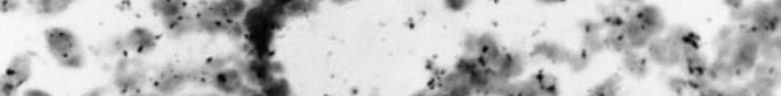

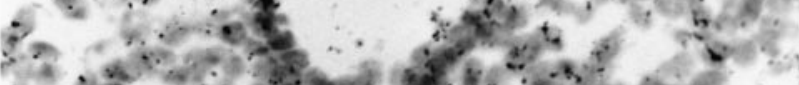

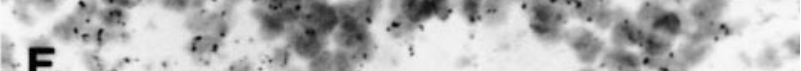

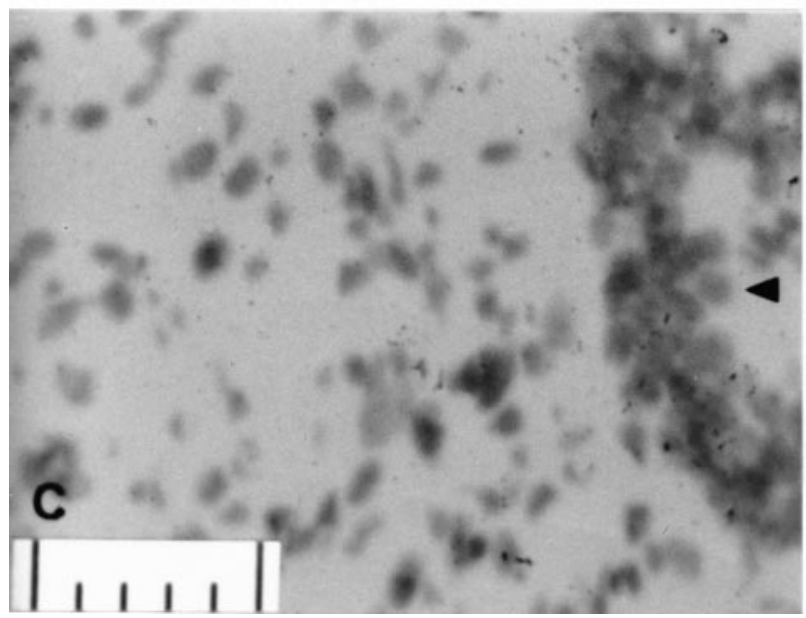

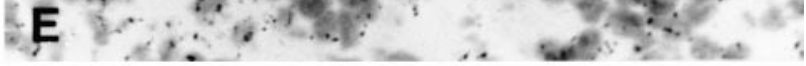

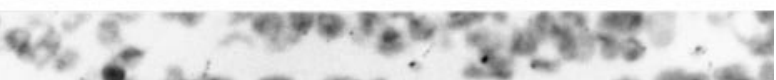

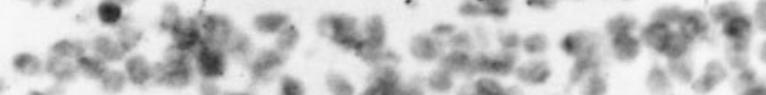

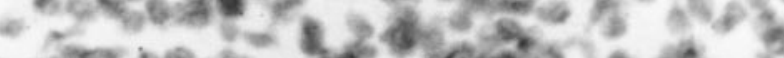

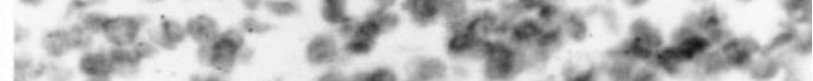

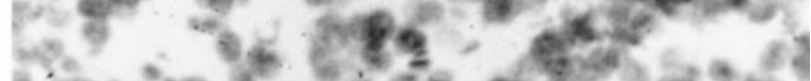

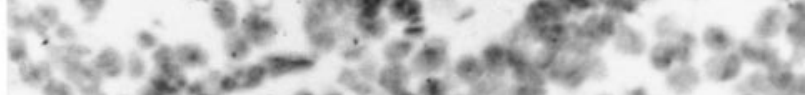

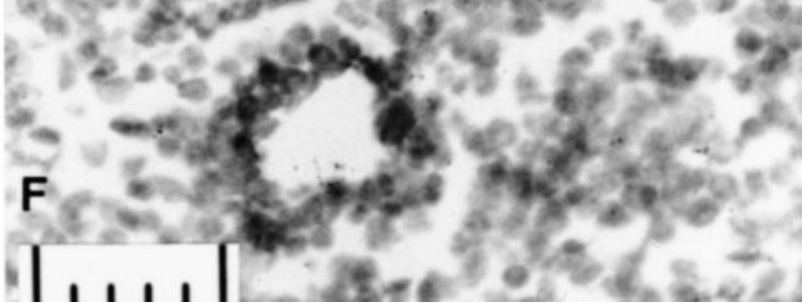


Clusterin therefore appears to be synthesised by the majority of cells in the ovine anterior and intermediate pituitary gland, but most of the protein appears to be in or around the capillaries. Evidence for synthesis of clusterin by capillary endothelial cells is somewhat contradictory. Clusterin is expressed in porcine vascular smooth muscle cells in culture and appears to be required for the formation of multicellular nodules in these cultures (Thomas-Salgar \& Millis 1994), suggesting that the protein functions as a cell adhesion molecule in in vitro differentiation. While clusterin expression is upregulated in studies of hypertension-induced microcapillary apoptosis in skeletal muscle, clusterin mRNA is not found to be localised in the endothelial cells (Gobe et al. 1997). Clusterin is also known to act as a serum complement inhibitor, rendering the terminal complement complex soluble and unable to insert into cell membranes (Tschopp et al. 1993). Berge et al. (1997) found some evidence of clusterin synthesis in human umbilical vein endothelial cells which was regulated by various proinflammatory cytokines (interleukins IL-1 and IL-6, and tumour necrosis factor), as well as interferon-gamma. The presence of clusterin immunoreactivity in endothelial cells does not necessarily imply its synthesis here, since clusterin has been shown to facilitate transport of soluble amyloid beta (1-40)-clusterin complexes across the cerebral vascular endothelium and choroid epithelium, via glycoprotein 330 (gp330)/megalin, the proposed receptor for clusterin (Zlokovic et al. 1996). Megalin is a member of the low-density lipoprotein receptor gene family and is expressed on the apical surfaces of epithelial tissues, where it mediates the endocytotic uptake of diverse macromolecules, such as cholesterol-carrying lipoproteins (including clusterin, also known as apolipoprotein J (Kounnas et al. 1995)), proteases and serum proteins including albumin (Cui et al. 1996). The question therefore arises as to whether the strong immunoreactivity observed in the lumen of capillaries in the ovine anterior and intermediate pituitary indicates secretion of the protein, or the uptake of clusterin-lipid or clusterin-protein complexes from the serum. It is possible that clusterin and gp330/megalin act together as a cellular waste management system within tissues, but studies on the distribution of the gp330/megalin molecule in this tissue are needed before this question can be answered.

In the pig, clusterin has been shown to form a high proportion of the colloid deposits that occur in the anterior pituitary gland of older animals (Ogawa et al. 1997). These insoluble complexes are found associated with non-secretory folliculo-stellate cells and increase in number with age in the pig and in some species after hibernation (Ogawa et al. 1997). Clusterin gene expression has been shown to be negatively controlled in vivo and in vitro by glucocorticoids, testosterone, progesterone and oestrogen, in a range of hormone-dependent tissues (Frasoldati et al. 1995, Furlong et al. 1996, Gutacker et al. 1996, Wunsche et al. 1998), but there is little evidence for steroid control of clusterin expression at the level of the gene promoter (Wilson et al. 1995). Because clusterin synthesis is induced in many hormone-dependent tissues after hormone ablation, the presence of pituitary colloid deposits in situations of decreased circulating steroid, such as senescence or hibernation, implies steroid control of clusterin uptake and/or synthesis in the anterior pituitary gland.

Alternatively, clusterin may act as a granin in the anterior pituitary and aid in hormone secretion in response to $\mathrm{Ca}^{2+}$ flux. Clusterin is found in the dense core secretory granules of endocrine tissues such as the adrenal medulla and pituitary gland, associated with granins such as secretogranin II and chromogranin B (Laslop et al. 1993), which are aggregated by increased $\mathrm{Ca}^{2+}$ concentrations and a $\mathrm{pH}$ of around 5.5 (Gerdes et al. 1989). Prolactin granulogenesis and secretion is upregulated by oestradiol-17 $\beta$ treatment in a GH4C1 pituitary tumour cell line (growth hormone cells) and this is associated with increased secretogranin II and chromogranin B expression and aggregation in the Golgi bodies and secretory granules (Thompson

FIGURE 3. Expression of clusterin mRNA and protein in serial sections of the ovine pituitary gland. (A-C) Serial sections at the transition between the intermediate lobe (I) and the posterior lobe (P). (A) Phase contrast immunohistochemistry, with a specific monoclonal antibody immunoglobulin against sheep clusterin. A single intermediate pituitary cell is stained with the anti-clusterin antibody (arrowhead). (B) In situ hybridisation with the

${ }^{33} \mathrm{P}$-labelled ovine clusterin antisense riboprobe, showing higher silver grain density in the intermediate lobe than in the posterior pituitary. The immunoreactive cell in (A) does not appear to be expressing more clusterin mRNA. (C) In situ hybridisation with the control sense riboprobe. (D-F) Serial sections within the ovine anterior pituitary. (D) Ovine anti-clusterin immunohistochemistry, demonstrating staining within a capillary and within some cells. (E) In situ hybridisation with the ${ }^{33} \mathrm{P}$-labelled ovine clusterin antisense riboprobe. Most anterior pituitary cells have silver grains associated with them. (F) In situ hybridisation with the control sense riboprobe. Scale bars in the bottom left of panel $(\mathrm{C})$ and $(\mathrm{F})$ represent $50 \mu \mathrm{m}$ with minor divisions of $10 \mu \mathrm{m}$. 

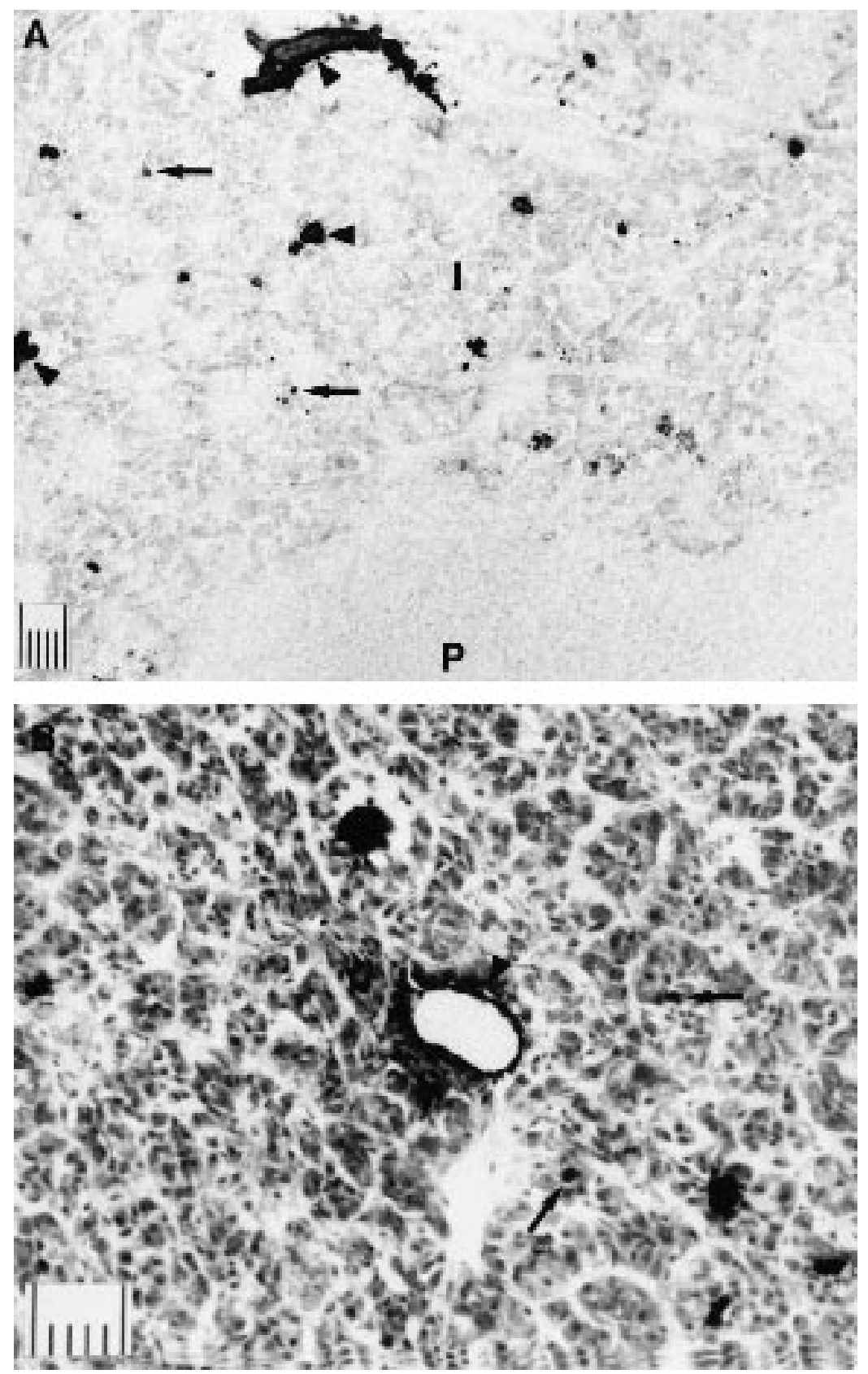

FIGURE 4. Clusterin immunoreactivity in the ovine pituitary gland. (A) A section through the posterior $(\mathrm{P})$ and intermediate (I) lobes, showing immunoreactive deposits in the capillary lumen (arrowheads) and in the occasional single cell (arrows). Scale bar represents $50 \mu \mathrm{m}$ with minor divisions of $10 \mu \mathrm{m}$. (B) Anterior pituitary gland anti-clusterin immunohistochemistry, counterstained with eosin, demonstrating staining in or on the capillary endothelium (arrow head) and within the capillaries. Isolated secretory pituitary cells are also stained (arrows). Scale bar represents $50 \mu \mathrm{m}$ with minor divisions of $10 \mu \mathrm{m}$. 
et al. 1992). Clusterin could therefore be acting as a granin, in a system of $\mathrm{Ca}^{2+}$-controlled hormone release (Gerdes et al. 1989, Chanat \& Huttner 1991, Thompson et al. 1992).

We conclude that clusterin is expressed by many cells in the ovine anterior and intermediate pituitary lobes. The high clusterin immunoreactivity observed in isolated single cells may be indicative of rare apoptotic events occurring within the anterior and intermediate lobes. Strong clusterin immunoreactivity in and around the capillaries, on the other hand, may be associated with megalinmediated lipid or lipoprotein uptake into the pituitary cells, or with hormone secretion from this endocrine tissue.

\section{ACKNOWLEDGEMENTS}

We thank our colleague Dr John Schofield (Department of Laboratory Animal Science), for assistance with animal killing. This research was supported by grants from the New Zealand Lottery Board (Health) and the University of Otago.

\section{REFERENCES}

Aronow BJ, Lund SD \& Brown TL 1993 Apolipoprotein J expression at fluid-tissue interfaces: potential role in barrier cytoprotection. Proceedings of the National Academy of Sciences of the USA 90 725-729.

Berge V, Johnson E \& Hágisen K 1997 Clusterin and the terminal complement pathway synthesized by human umbilical vein endothelial cells are closely linked when detected on co-cultured agarose beads. Acta Pathologica, Microbiologica et Immunologica Scandinavica 105 17-24.

Bettuzzi S, Zoli M, Ferraguti F, Ingletti MC, Agnati LF \& Corti A 1992 Regional and cellular distribution within the rat prostate of two mRNA species undergoing opposite regulation by androgens. Fournal of Endocrinology 132 361-367.

Blaschuk OW \& Fritz IB 1984 Isoelectric forms of clusterin isolated from ram rete testis fluid and from secretions of primary cultures of ram and rat Sertoli-cell-enriched preparations. Canadian Fournal of Biochemistry and Cell Biology 62 456-461.

Burkitt HG, Young B \& Heath JW 1993 Wheater's Functional Histology. A Text and Colour Atlas. Melbourne: Churchill Livingstone.

Chanat E \& Huttner WB 1991 Milieu-induced, selective aggregation of regulated secretory proteins in the trans-Golgi network. Fournal of Cell Biology 115 1505-1519.

Cheng CY, Chen C-LC, Feng Z-M, Marshall A \& Bardin CW 1988 Rat clusterin isolated from primary Sertoli cell-enriched culture medium is sulfated glycoprotein-2 (SGP-2). Biochemical and Biophysical Research Communications 155 398-404.

Cui S, Verroust PJ, Moestrup SK \& Christensen EI 1996 Megalin/gp330 mediates uptake of albumin in renal proximal tubule. American Fournal of Physiology 271 F900-F907.
Feinberg AP \& Vogelstein B 1983 A technique for radiolabelling DNA restriction endonuclease fragments to high specific activity. Analytical Biochemistry 132 6-13.

Finch CE \& May PC 1995 Recent findings on clusterin in neural tissues: neuroanatomy, cell sources, development and ageing, Alzheimer Disease and other brain lesions. In Clusterin: Role in Vertebrate Development, Function and Adaptation, pp 164-184. Ed JAK Harmony. New York: RG Landes Company, Springer-Verlag.

Fleming JS, Greenwood PJ \& Chen CLC 1992 Expression of the clusterin gene in the tissues of Booroola sheep which were homozygotes or non-carriers of the fecundity gene $\mathrm{Fec}^{\mathrm{B}}$. Fournal of Molecular Endocrinology 9 207-211.

Fleming JS, Suttie JM, Montgomery GW, Gunn J, Stuart SK, Littlejohn RP \& Gootwine E 1997 The effects of a duplication in the ovine growth hormone $(\mathrm{GH})$ gene on $\mathrm{GH}$ expression in the pituitaries of ram lambs from lean and fat-selected sheep lines. Domestic Animal Endocrinology 14 $17-24$.

Frasoldati A, Zoli M, Rommerts FFG, Biagini G, Fustini MF, Carani C, Agnati LF \& Marrama P 1995 Temporal changes in sulphated glycoprotein-2 (clusterin) and ornithine decarboxylase mRNA levels in the rat testis after ethanedimethane sulphonate-induced degeneration of Leydig cells. International Fournal of Andrology 18 46-54.

Fritz IB 1995 Introduction to clusterin: history and perspectives. In Clusterin: Role in Vertebrate Development, Function and Adaptation, pp 1-12. Ed JAK Harmony. New York: RG Landes Company, Springer-Verlag.

Fritz IB \& Murphy B 1993 Clusterin - insights into a multifunctional protein. Trends in Endocrinology and Metabolism 4 41-45.

Furlong EEM, Keon NK, Thornton FD, Rein T \& Martin F 1996 Expression of a 74-kDa nuclear factor 1 (Nf1) protein is induced in mouse mammary gland involution - involutionenhanced occupation of a twin Nf1 binding element in the testosterone-repressed prostate message-2/clusterin promoter. Fournal of Biological Chemistry 271 29688-29697.

Gerdes HH, Rosa P, Phillips E, Baeuerle PA, Frank R, Argos P \& Huttner WB 1989 The primary structure of human secretogranin II, a widespread tyrosine-sulfated secretory granule protein that exhibits low $\mathrm{pH}$ - and calcium-induced aggregation. Fournal of Biological Chemistry 264 12009-12015.

Gobe G, Browning J, Howard T, Hogg N, Winterford C \& Cross R 1997 Apoptosis occurs in endothelial cells during hypertension-induced microvascular rarefaction. Fournal of Structural Biology 118 63-72.

Gong Z 1992 Improved RNA staining in formaldehyde gels. Biotechniques 1274.

Gutacker C, Flach R, Diel P, Klock G \& Kochbrandt C 1996 Multiple signal transduction pathways regulate clusterin $(\mathrm{Gp}$ 80) gene expression in MDCK cells. Fournal of Molecular Endocrinology 17 109-119.

Kounnas MZ, Loukinova EB, Stefansson S, Harmony JA, Brewer BH, Strickland DK \& Argraves WS 1995 Identification of glycoprotein 330 as an endocytic receptor for apolipoprotein J/clusterin. Fournal of Biological Chemistry 270 13070-13075.

Laslop A, Steiner HJ, Egger C, Wolkersdorfer M, Kapelari S, Hogue-Angeletti R, Erickson JD, Fischer-Colbrie R \& Winkler H 1993 Glycoprotein III (clusterin, sulfated glycoprotein 2) in endocrine, nervous, and other tissues: immunochemical characterization, subcellular localization, and regulation of biosynthesis. Fournal of Neurochemistry 61 1498-1505.

Leeuwenberg BR, Hurst PR \& McNatty KP 1995 Expression of IGF-I mRNA in the ovine ovary. Fournal of Molecular Endocrinology 15 251-258. 
Messmer-Joudrier S, Sagot Y, Mattenberger L, James RW \& Kato AC 1996 Injury-induced synthesis and release of apolipoprotein $\mathrm{E}$ and clusterin from rat neural cells. European Fournal of Neuroscience 8 2652-2661.

Ogawa S, Ishibashi Y, Sakamoto Y, Kitamura K, Kubo M, Sakai T \& Inoue K 1997 The glycoproteins that occur in the colloids of senescent porcine pituitary glands are clusterin and glycosylated albumin fragments. Biochemical and Biophysical Research Communications 234 712-718.

Palmer DJ \& Christie DL 1990 The primary structure of glycoprotein III from bovine adrenal medullary chromaffin granules. Fournal of Biological Chemistry 265 6617-6623.

Rosenior J, Tung PS \& Fritz IB 1987 Biosynthesis and secretion of clusterin by ram rete testis cell-enriched preparations in culture. Biology of Reproduction 36 1313-1320.

Scaglia L, Smith FE \& Bonnerweir S 1995 Apoptosis contributes to the involution of beta cell mass in the post partum rat pancreas. Endocrinology 136 5461-5468.

Sylvester S \& Griswold M 1995 The reproductive biology of clusterin. In Clusterin: Role in Vertebrate Development, Function and Adaptation, pp 141-157. Ed JAK Harmony. New York: RG Landes Company, Springer-Verlag.

Tenniswood MP, Guenette RS, Lakins J, Mooibroek M, Wong P \& Welsh JE 1992 Active cell death in hormone-dependent tissues. Cancer and Metastasis Reviews 11 197-220.

Thomas-Salgar S \& Millis AJT 1994 Clusterin expression in differentiating smooth muscle cells. Fournal of Biological Chemistry 269 17879-17885.

Thompson ME, Zimmer WE, Haynes AL, Valentine DL, Forss-Petter S \& Scammell JG 1992 Prolactin granulogenesis is associated with increased secretogranin expression and aggregation in the Golgi apparatus of GH4C1 cells. Endocrinology 131 318-326.

Tornquist E, Liu L, Aldskogius H, Vonholst H \& Svensson M 1996 Complement and clusterin in the injured nervous system [Review]. Neurobiology of Aging 17 695-705.

Tornquist E, Liu L, Mattsson P \& Svensson M 1997 Response of glial cells and activation of complement following motorneuron degeneration induced by toxic ricin. Neuroscience Research 28 167-175.
Tschopp J, Chonn A, Hertig S \& French LE 1993 Clusterin, the human apolipoprotein and complement inhibitor, binds to complement-C7, C8-beta, and the $\beta$-domain of $\mathrm{C} 9$. fournal of Immunology 151 2159-2165.

Tung PS \& Fritz IB 1985 Immunolocalization of clusterin in the ram testis, rete testis, and excurrent ducts. Biology of Reproduction 33 177-186.

Walton M, Young D, Sirimanne E, Dodd J, Christie D, Williams C, Gluckman P \& Dragunow M 1996 Induction of clusterin in the immature brain following a hypoxic-ischemic injury. Molecular Brain Research 39 137-152.

Welsh J 1994 Induction of apoptosis in breast cancer cells in response to vitamin $\mathrm{D}$ and antiestrogens - review. Biochemistry and Cell Biology 72 537-545.

Wener KM, Morales CR \& Brawer JR 1997 The effect of estradiol-induced hypothalamic pathology on sulfated glycoprotein-2 (clusterin) expression in the hypothalamus. Brain Research 745 37-45.

Wilson MR, Easterbrook-Smith SB, Lakins J \& Tenniswood MPR 1995 Mechanisms of induction and function of clusterin at sites of cell death. In Clusterin: Role in Vertebrate Development, Function and Adaptation, pp 75-100. Ed JAK Harmony. New York: RG Landes Company, Springer-Verlag.

Wunsche W, Tenniswood MP, Schneider MR \& Vollmer G 1998 Estrogenic regulation of clusterin mRNA in normal and malignant endometrial tissue. International Fournal of Cancer 76 684-688.

Zlokovic BV, Martel CL, Matsubara E, McComb JG, Zheng G, McCluskey RT, Frangione B \& Ghiso J 1996

Glycoprotein 330/megalin: probable role in receptormediated transport of apolipoprotein $\mathrm{J}$ alone and in a complex with Alzheimer disease amyloid beta at the blood-brain and blood-cerebrospinal fluid barriers. Proceedings of the National Academy of Sciences of the USA 93 4229-4234.

Zwain IH, Grima J \& Cheng CY 1994 Regulation of clusterin secretion and mRNA expression in astrocytes by cytokines. Molecular and Cellular Neurosciences 5 229-237.

REVISED MANUSCRIPT RECEIVED 4 May 1999 